\title{
De 1867 a 2017: o Canadá e as suas múltiplas reinvenções ${ }^{1}$
}

\author{
Adina Balint - Universidade de Winnipeg \\ Zilá Bernd - Unilasalle/CNPq \\ Editoras convidadas do dossiê sobre os 150 anos da Confederação Canadense ${ }^{2}$ \\ Não há nenhuma narrativa principal da história canadense: \\ Há inúmeras histórias reunidas em uma identidade rigorosamente e firmemente escrita. \\ Charlotte Gray, The Promise of Canada ${ }^{3}$
}

Em 2017, a Confederação Canadense comemora o seu $150^{\circ}$ aniversário de

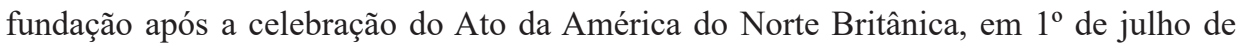
1867. Desde então, as colônias do Canadá Unido (dividida, na sequência, nas provinciais de Ontário e Quebec), do Novo Brunswick e da Nova Escócia, reunidas no Domínio de Canadá, adquiriram a sua independência política e integraram outros territórios até formarem o grande país que conhecemos hoje. Desde o início, a coexistência de culturas e línguas diferentes foi um dos principais traços do Canadá e da identidade canadense.

Ao longo dos 150 últimos anos, as Primeiras Nações e os povos descendentes dos primeiros colonos franceses e ingleses, assim como os canadenses de outras origens etnoculturais, contribuíram todos para redefinir a identidade nacional alimentada pelas recentes noções de multiculturalismo e bilinguismo. No século XX, esta essencial diversidade constitui a base da canadianidade também na esfera legislativa, através, notadamente, da promulgação da Lei sobre as Línguas Oficiais (1969) e da Lei sobre o Multiculturalismo (1988) e da criação do território de Nunavut, em 1999. Em 2017, 150 anos após a Confederação, o pluralismo permanece no âmago da identidade canadense, mesmo se - e justamente por - ao longo das últimas décadas, a política e as representações culturais do multiculturalismo canadense terem sido objeto de questionamentos e debates, em resonância com os desafios trazidos pelo novo milênio e pelas crises da imigração.

$\mathrm{O} 150^{\circ}$ aniversário da Confederação Canadense é um momento propício à reflexão sobre as narrativas identitárias, as decisões políticas e as transformações que contribuíram para forjar o Canadá moderno. Reexaminar a diversidade canadense coloca à prova as narrativas tradicionais e nos convida a elaborar discursos críticos e inovadores. Como se manifestam a criatividade, a reflexão crítica, as práticas artísticas quando se trata de 
repensar o Canadá? Quais são os discursos cultural, histórico e estético que destacam as transformações do Canadá desde 1867? Como a Comissão da Verdade e da Reconciliação desconstrói os mitos da colonização e do nacionalismo canadense? E como o Canadá continua amarrado a uma história colonial que marginaliza os povos autóctones e explora os recursos naturais? Ou ainda, como a imigração e as recentes ondas de refugiados questionam a identidade canadense? Enfim, como o multiculturalismo, as línguas e os valores plurais podem nos conduzir a melhor compreender o $150^{\circ}$ aniversário do Canadá?

Tomando em consideração a complexidade destas questões, o dossiê $D e$ 1867 a 2017: O Canadá e as suas múltiplas reinvenções propõe repensar a trajetória sociocultural, geopolítica e estética do país que chamamos hoje de Canadá. Assim, Adina Balint e Patrick Imbert exploram as relações entre as representações históricas, literárias e artísticas do Canadá, a fim de demonstrar que 'restorying Canada' significa questionar as narrativas memoriais e tradicionais, reler a história e inventar narrativas inovadoras e inclusivas. Na mesma perspectiva, Zilá Bernd nos adverte sobre a armadilha das exclusões alimentadas pelos discursos identitários nacionalistas. Através da noção de "comunidades de memória" (P. Ouellet), Bernd realça a importância da partilha de histórias e memórias para uma redefinição das identidades para além de tensões étnicas, geográficas ou nacionais.

Ao passo que os dois primeiros artigos tratam das noções de multiculturalismo, transculturalismo e interculturalismo, o estudo proposto por Licia Soares de Souza dos editoriais publicados pelo jornal La Presse, de Montreal, no ano de 1885, analisa a questão das rebeliões dos Métis do Oeste canadense no final do século XIX e de suas consequências sobre a maneira através da qual o "federalismo" é percebido no Quebec e nas comunidades francófonas minoritárias do Canadá. Souza emprega uma leitura dialética de trechos de La Presse de maneira a revelar os pontos de tensão entre os Métis e os colonos. Por sua vez, Luciana Wrege Rassier e Jean-François Brunelière sublinham que é possível despertar diálogos transculturais entre autóctones e não autóctones no Quebec e no Canadá. Tratar-se-ia de iniciar uma escuta mutuamente respeitosa, uma tomada de consciência das singularidades e diferenças, o reconhecimento dos erros e das injustiças e uma luta comum contra os estereótipos culturais e o racismo. A questão 
da inclusão e da partilha da diversidade etnocultural também é explorada por Alain-G. Gagnon e François Boucher em um artigo traduzido do francês para o português por Oscar Augusto Berg. Os autores discutem o interculturalismo quebequense como um modelo bem sucedido de integração, suscetível de inspirar outras sociedades liberais e democráticas ao redor do globo.

Ainda em uma perspectiva de abertura e de partilha, Michel Peterson abre as discussões para o Caribe. Ele se interessa pelas dinâmicas de construção de imaginários e pelas práticas de solidariedade próprias às coletividades caribenhas da diáspora de Montreal. Desta forma, ele mostra que a riqueza de representações simbólicas das festas e celebrações, a literatura e a música, assim como as redes de solidariedade entre diversas comunidades constituem elementos essenciais para repensar os fundamentos dos imaginários caribenhos. A partir destes imaginários, seria possível impulsionar, posteriormente, transformações positivas das práticas sociais das comunidades contemporâneas no Canadá e no mundo.

Como percebemos, a evocação do $150^{\circ}$ aniversário da Confederação é feita de momentos de intensa luminosidade e de outros períodos menos facilmente distinguíveis, mas que convém compreender. Em nosso contexto de "interfaces" Brasil-Canadá, é preciso, nos parece, continuar a renovar as reflexões sobre as transferências entre as culturas, sobre a partilha e a troca de experiências e aprendizagens. Este número de Interfaces Brasil-Canadá, graças às suas abordagens multidisciplinares e comparatistas, busca a renovar o pensamento sobre os elementos desencadeadores, os pontos de ruptura e a trajetória - necessariamente complexa - que permitiram forjar o Canadá moderno. Pelo estudo de textos nas línguas francesa, inglesa e portuguesa, assim como pela exploração de produções estéticas de origem autóctone, nós buscamos desenhar um retrato - ainda que breve - dos desafios socioculturais que animam os imaginários e as representações do Canadá atualmente. Finalmente, este dossiê se apresenta como um mosaico no qual discursos múltiplos e vozes em diferentes línguas, do Canadá ao Brasil e do Brasil ao Canadá, estão presentes. 


\section{Nota}

${ }^{1}$ Tradução do francês por Oscar Berg - NEC Unilasalle e mestrando PUCRS

${ }^{2}$ Nosso especial agradecimento à incansável e eficiente colaboração de Oscar Berg e nossa admiração por sua paixão pelos Estudos Canadenses.

${ }^{3}$ Charlotte Gray, The Promise of Canada, Toronto: Simon \& Schuster Canada 2016, p. XIV 